\title{
Estudo da distribuição e dos territórios das artérias cerebrais rostral, média e caudal e cerebelares rostral, média e caudal na superfície do encéfalo em Didelphis albiventris (gambá)*
}

\author{
TÂNIA LINDEMANN
}

Rui Campos (Orientador - UFRGS)

Banca: Amilton V. Marçal (PUCRS), Irvênia L. S. Prada (USP), Matilde Achaval (UFRGS)

Estudaram-se as artérias cerebrais e cerebelares rostral, média e caudal na superfície do encéfalo de 30 Didelphis albiventris, 14 machos e 16 fêmeas, com o sistema arterial preenchido com Látex 603 pigmentado, e fixados em formol $20 \%$. Sistematizaram-se as artérias e seus principais ramos, determinando a área territorial de irrigação e as principais variações. A artéria cerebral rostral apresentou-se à direita em $100 \%$ das peças e à esquerda esteve presente em $96,7 \%$ e ausente em 3,3\% dos casos. Dividiu-se em ramo medial, tronco hemisférico rostral, ramo lateral e artéria lateral do bulbo olfatório, presentes em $100 \%$ das amostras, bilateralmente. O tronco hemisférico rostral bifurcou-se em ramo rostral, artéria medial do bulbo olfatório, presente em todas as peças em ambos os antímeros, e ramo caudal, artéria inter-hemisférica rostral. Esta originou-se conforme o padrão em $90 \%$ dos casos à direita e em $86,7 \%$ à esquerda, nas amostras restantes teve origem de um ramo emitido pelo antímero oposto. A artéria cerebral média, presente em todos os casos nos dois antímeros, apresentou os seguintes ramos colaterais: ramos ventrorostrais presentes em $66,7 \%$ das preparações; ramo ventrocaudal medial para o lobo piriforme, presente em $100 \%$ das amostras à direita e em $83,3 \%$ à esquerda; ramo ventrocaudal lateral para o lobo piriforme, presente em $100 \%$ das peças nos dois antímeros; $1^{\circ}$ ramo hemisférico dorsolateral presente em $93,3 \%$ dos encéfalos à direita, e em $90 \%$ à esquerda; $2^{\circ}$ ramo hemisférico dorsolateral presente em $36,6 \%$ das peças bilateralmente; ramo dorso-rostral presente à direita em $56,7 \%$ das amostras e à esquerda em $80 \%$ das preparações. A artéria cerebral média continua-se como ramo terminal em todos os casos, bilateralmente. A artéria cerebral caudal, presente bilateralmente em todas as peças, originou: ramo hemisférico tentorial em $83,3 \%$ dos casos à direita e em $80 \%$ à esquerda, este ramo originou-se da artéria comunicante caudal em $10 \%$ das peças nos dois antímeros ou ainda originou-se do tronco cerebral médio-rostral em 6,7\% à direita e em $10 \%$ das preparações à esquerda; artéria tectal rostral à direita ímpar em 96,7\% e dupla em 3,3\% dos casos e à esquerda ímpar em $100 \%$ das peças. O ramo terminal da artéria cerebral caudal originou a artéria inter-hemisférica caudal em $93,3 \%$ das amostras à direita e em $86,7 \%$ à esquerda. A artéria cerebelar rostral originou-se como continuação natural do ramo terminal da artéria basilar em 93,3\% dos casos, bilateralmente, percorrendo as faces rostral e dorsal dos hemisférios cerebelares, formando por sobre estes uma alça. Em 6,7\% das amostras não formou uma alça. A artéria tectal caudal apresentou-se à direita ímpar em 83,3\% e dupla em 16,7\% das peças, à esquerda ímpar em $86,7 \%$, dupla em $10 \%$ e ausente em 3,3\% das amostras. A artéria cerebelar média à direita mostrou-se dupla em $70 \%$ e ímpar em $30 \%$ das peças, à esquerda, dupla em 56,7\% e ímpar em 43,3\% dos achados. A artéria cerebelar caudal apresentou-se à direita ímpar em 93,3\% e dupla em 6,7\% das peças e à esquerda ímpar em $86,7 \%$ e dupla em $13,3 \%$ das amostras.

Descritores: irrigação encefálica, artérias cerebrais, marsupiais.

Apresentada: 19 agosto 2002

\footnotetext{
* Tese de Doutorado n. 17 (Especialidade: Anatomia Animal). 154f. Programa de Pós-Graduação em Ciências Veterinárias, Faculdade de Veterinária de Porto Alegre - UFRGS. CORRESPONDÊNCIA: T. Lindemann [e-mail: lindemann@orion.ufrgs.br].
} 


\title{
Study of distribution and territories of the rostral, middle and caudal cerebral arteries and rostral, middle and caudal cerebellar arteries on the surface of the brain in Didelphis albiventris (opossum)**
}

\author{
TÂNIA LINDEMANN
}

\author{
Rui Campos (Adviser - UFRGS)
}

Committee: Amilton V. Marçal (PUCRS), Irvenia L. S. Prada (USP), Matilde Achaval (UFRGS)

The rostral, middle and caudal cerebral and cerebellar arteries were studied on the surface of the brain in 30 Didelphis albiventris, 14 males and 16 females, with the arterial system filled with colored latex and fixed in $20 \%$ formaldehyde solution. The arteries and its main branches were systematized, determined the irrigation territorial area and the main variations. The rostral cerebral artery was seen on the right in $100 \%$ of the preparations, on the left it was present in $96.7 \%$ and absent in $3.3 \%$ of the cases. This vessel was divided into medial branch (rostral hemispheric trunk) and lateral branch (olfactory bulb lateral artery) present bilaterally in $100 \%$ of samples. The rostral hemispheric trunk bifurcated into a rostral branch, olfactory bulb medial artery, present in all pieces in both antimeres and in a caudal branch, rostral inter-hemispheric artery. The latter was originated according to the pattern on the right in $90 \%$ of the cases and on the left in $86.7 \%$, and on the remaining samples was originated from a branch emitted by the opposite antimere. The middle cerebral artery, present in all cases in both antimeres, showed the following collateral rami: the ventrorostral branches in $66.7 \%$ of the pieces; the medial ventrocaudal ramus present in $100 \%$ of the samples on the right and $83.3 \%$ on the left; the lateral ventrocaudal ramus present in $100 \%$ of the samples in both antimeres; the $1^{\circ}$ dorsolateral hemispheric branch present in $93.3 \%$ of the cases on the right and in $90 \%$ on the left; $2^{\circ}$ dorsolateral hemispheric branch present bilaterally in $36.6 \%$ of the pieces; the dorsorostral branch present on the right in $56.7 \%$ and on the left in $80 \%$ of the preparations. The middle cerebral artery went on as a terminal ramus bilaterally in all cases. The caudal cerebral artery present bilaterally in all pieces originated: the tentorial hemispheric branch in $83.3 \%$ of the cases on the right and $80 \%$ on the left, this branch was originated from the caudal communicating artery in $10 \%$ of the pieces in both antimeres or yet was originated from the rostral-middle cerebral trunk in $6.7 \%$ on the right and in $10 \%$ on the left; the rostral tectal artery on the right single in $96.7 \%$ and double in $3.3 \%$ of the cases and on the left single in $100 \%$ of the pieces. The terminal branch of the caudal cerebral artery originated the caudal interhemispheric artery in $93.3 \%$ of the samples on the right and in $86.7 \%$ on the left. The rostral cerebellar artery was originated as a natural continuation of the terminal branch of the basilar artery in $93.3 \%$ of the cases, bilaterally, running to the dorsal and rostral surfaces of the lateral cerebellar hemispheres and forming right above it a loop. The caudal tectal artery was present single on the right in $83.3 \%$ and double in $16.7 \%$ of the pieces, on the left single in $86.7 \%$, double in $10 \%$ and absent in $3.3 \%$ of the samples. The middle cerebellar artery on the right was seen double in $70 \%$ and single in $30 \%$ of the preparations, on the left double in $56.7 \%$ and single in $43.3 \%$ of the findings. The caudal cerebellar artery was present single on the right in $93.3 \%$ and double in $6.7 \%$ of the pieces and on the left single in $86.7 \%$ and double in $13.3 \%$ of the cases.

Key words: encefalic irrigation, cerebral arteries, marsupials.

\footnotetext{
**Doctoral Dissertation no. 17 (Field: Veterinary Anatomy). 154p. Postgraduate Program in Veterinary Sciences, Faculdade de Veterinária de Porto Alegre, Universidade Federal do Rio Grande do Sul (UFRGS) - Brazil. CORRESPONDENCE: T. Lindemann [e-mail: lindeman@orion.ufrgs.br].
} 